\title{
"Kampung" as a Formal and Informal Integration Model (Case Study: Kampung Pahandut, Central Kalimantan Province, Indonesia)
}

\author{
Noor Hamidah ${ }^{* 1,4}$, R. Rijanta ${ }^{2}$, Bakti Setiawan ${ }^{3}$, Muh. Aris Marfai ${ }^{2}$ \\ ${ }^{1}$ Doctoral Program, Faculty of Geography, Universitas Gadjah Mada, Indonesia. \\ ${ }^{2}$ Faculty of Geography, Universitas Gadjah Mada, Indonesia. \\ ${ }^{3}$ Department of Architecture and Urban Planning, Universitas Gadjah Mada, Indonesia. \\ ${ }^{4}$ Department of Architecture and Urban Planning, Universitas Palangka Raya, Indonesia \\ * Corresponding author (e-mail: noor.hamidah@mail.ugm.ac.id)
}

Received: 13 January 2017 / Accepted: 13 June 2017 / Published: 01 July 2017

\begin{abstract}
Kampung is a mixed formal and informal settlements which has a long history. Kampung has always been occupied by millions of in Indonesia. Kampung shows its capacity to integrate formal and informal activities both within the kampung itself and activities at city level. This research try to explore Kampung Pahandut, Central Kalimantan Province, Indonesia as a case study of embryo settlement close to the river. The objective of this research is to describe of formal and informal in formal and informal activities within Kampung Pahandut. This research attempt to study the pattern and the forms of socio-economic integration of the community. This research applies mixed method (qualitative and quantitative) through field observation as a step to find the integration of formal and informal activity in Kampung. Data collection is primarily to record both social and economic activities since field observation records physical appearances of infrastructure. In addition, this Kampung research was also conducted through in-depth interview to explore information from the selected resource persons. This research approves that Kampung, in the case of Kampung Pahandut, is not separated both physical and social from the city of Palangka Raya. It is reveal that internal social activity of Kampung are able to maintain 'gotong-royong' and external social activity showed by 'green kampung'. Kampung Pahandut is a part of the Palangka Raya city government by kampung improvement program. It means integration through physical and social activities shows that kampungs are not isolation settlements. Kampung has its significant contributions to the social and physical of the Palangka Raya city. It is as proven by formal and informal activities of Kampung Pahandut which is found to be fully integrated to the city of Palangka Raya.
\end{abstract}

Keywords: Kampung, formal settlement, informal settlement, formal-informal integration, settlement, Kahayan River.

Abstrak. Kampung merupakan perpaduan permukiman formal dan informal melalui sejarah panjang. Kampung dihuni oleh jutaan penduduk di Indonesia. Kampung menunjukkan keberagaman aktivitas formal dan informal, baik aktivitas dalam kampung maupun aktivitas kampung terhadap kota. Penelitian ini mengeksplorasi Kampung Pahandut, di Kota Palangka Raya, Provinsi Kalimantan Tengah, Indonesia sebagai kasus permukiman awal di tepian sungai. Penelitian ini bertujuan untuk mendeskripsikan integrasi formal dan informal dalam aktivitas formal dan informal kampung. Penelitian ini mengeksplorasi integrasi sosial ekonomi di lingkungan masyarakat kampung. Metode penelitian menggunakan metode gabungan (kualitatif dan kuantatif) melalui penelitian lapangan sebagai cara untuk menemukan aktivitas integrasi formal dan informal dalam kampung. Penelitian kampung merupakan data lapangan terkait aktivitas sosial dan ekonomi, fisik infrastruktur, termasuk wawancara mendalam dengan informan kunci untuk memperoleh informasi yang komprehensif. Kampung Pahandut terbukti sebagai bagian yang tidak terpisah dari sosial dan spasial Kota Palangka Raya. Penelitian ini menunjukkan integrasi sosial internal penduduk kampung yaitu gotong-royong dan integrasi sosial eksternal antara penduduk kampung dengan penduduk kota melalui aktivitas 
promosi 'green kampung'. Kampung Pahandut merupakan bagian administrasi Kota Palangka Raya melalui program perbaikan kampung. Penelitian integrasi formal dan informal secara fisik dan sosial menunjukkan bahwa kampung tidak terisolasi dari kota. Kampung Pahandut secara fisik merupakan wilayah administratif dari Kota Palangka Raya. Penelitian integrasi fisik menunjukkan bahwa Kampung merupakan bagian permukiman kota. Kampung memberikan kontribusi yang signifikan bagi kota baik sosial maupun fisik kampung. Penelitian ini membuktikan keberadaan kampung merupakan bagian aktivitas formal dan informal yang terintegrasi dengan kota.

Kata Kunci: Kampung, permukiman formal, permukiman informal, integrase formal-informal, permukiman, Sunagi Kahayan.

\section{Introduction}

Sustainable settlement development in Indonesia has dualism in terms of formal and informal aspects. This dualism settlement is a new phenomenon in some areas of Indonesian cities (Baiquni, 2000). Policies and programs of housing and settlement development tend to adopt it as a one-step regularisation, which means the regularisation of housing delivery system in one step (Lim, 1987). One-step regularisation policy is driven by an obsession to supply housing 'only' through the mechanism of the 'formal' development through organised control by both technical requirements and procedures of formal development (Doebelle, 1987). There are so many implemented elaboration of policy obsessions with one-step regularisation, such as a variety of 'informal' program resettlement. However, one-step regularisation policy in Indonesia disregards harmonisation in the provision of housing and settlement system in Indonesia, which is very dynamic and complex with the crisscross between the 'formal' and 'informal' as dualism in the mechanism of housing.

Since 1960's the policy maker and urban planner have discussed terms of 'developing' and 'developed' to have their roots on the thinking of dualism or dichotomous model of development paradigm. Hart (1973) argues that there are two terms, followed by the later terms of 'informal' and 'formal' sector. The two terms intensively discussed by scholars and policy maker focusing on the concept of 'sustainable development', 'empowerment', 'social capital', and 'economic development'. The optimistic point of view is the dichotomous or dualism model, particularly of formal and informal sector. Dualism model is basically appear in the early 1970's as a part of the acceptance of the informal sector concept as a foundation of the birth of new development paradigm. The policy and practical levels views of this dualism or dichotomous thinking of formal and informal sector tend to be misunderstood at the policy and practical level, followed by two contradictive approaches: (i) first, eviction of informal trading and transport activities operating in inner urban areas, and (ii) second, assisting capital and technological skills for home-based informal activities.

In his research on the housing scheme of informal sector workers, Sastrosasmito (1990) found that the housing problems of informal sector workers are out of the attention of government policy. Although the housing sector is provided by the government through housing program for low-income urban families, there is still no program to meet the need of majority of the informal sector workers who have no access to the official housing program due to the absence of formal collateral. Sastrosasmito (1990) research finding indicates an optimistic conclusion that it is rational to provide a housing scheme for the informal sector workers if the government is willing to give them guarantee for a housing loan, as what it does for the formal sector workers. His findings show that the ability and willingness to pay on the part of informal sector workers can satisfy the monthly repayment of formal housing which is provided for the formal sector workers. Rental accommodation in the kampung is the common feature of the housing status of the workers. Informal sector workers are provided with a rental house on rental land.

Formal and informal sector are two contradictive approaches in the context of urban settlements. One, slum upgrading projects is a part of pro-informal settlements. Two, 
urban renewal projects is a part of pro-formal settlements which were taken together as major solution for urban settlement problems. These contradictive approaches (slum upgrading and urban renewal) tend to be ended by favouring the formal approach (urban renewal) rather than informal approach. Sastrosasmito (1992) has explored urban settlement which is related to urban slum upgrading projects and urban renewal projects. Urban slum upgrading project and urban renewal project were taken together as major solution for urban settlements problems. Sastrosasmito (1992) proved that the integration of the settlements to urban structure in KIP project is still appropriate and realistic to be taken as a major strategy to solve the future housing problem of low-income urban families, particularly of the Indonesian middleclass society. The informal approach by KIP or slum upgrading project is more appropriate than urban renewal approach to maintain kampung in big cities of Indonesia.

The national policy has implemented the urban renewal approaches to make it popular in the context of urban development under its new labels such as '1000 apartment towers', 'superblock', 'apartment' rented apartment (rumah susun sewa), and ownership apartment (rumah susun milik). Many urban renewal projects indicate some speculation practices, shown by low occupancy of the buildings. The demand or the market of high-rise apartments is not a real demand or a real market. It is a quasi-demand, or a quasi-market. There is a tendency that these approaches in Jakarta tend to be followed by other cities of Indonesia (Kusno, 2012). Urban renewal reveals that there is no any integration of the projects to the old settlements and to the city level functions.

One of the real phenomena in Indonesia is a slum upgrading approach. Kampung has long history as informal settlements occupied by millions of people in the country (Rahardjo, 2010). Kampung is implemented as slum upgrading approach and a part of integration settlement model. Integration is one alternative solution to solve settlement problem in Indonesia. Integration model refers to PeBBu (2004) as one descriptive model to identify formal and informal integration. Model slum upgrading is a model of integration in the formal and informal settlements as a kampung. The term integration means integrating the whole of the various elements or certain element units. Integration model as an alternative or one solution of dichotomist settlement models that separate settlement between formal and informal settlements. Integration model is a new theory with limited research by urban planners and policy makers. Integration model is expected to be able to bridge the dualism of formal and informal settlements in Indonesia, particularly improved settlement.

This paper deals with how urban policy confronts the challenge of working with new innovative schemes not only to address the traditional needs of informal settlements such as housing, basic service, and land tenure security, but also to incorporate the conservation of the environment where these settlements are located. Indonesian government is trying to enhance the effectiveness of the formal settlement by providing access to the basic elements of housing development which tends to be limited. The research is particularly only exploring formal and informal integration by social aspect of kampung in urban riverside settlement through a case study in Kampung Pahandut, Pahandut District, Palangka Raya, Central Kalimantan Province, Indonesia (see Figure 1).

One case study in riverside area namely Kampung Pahandut. Kampung is an old kampung located along Kahayan River. Kampung Pahandut is an embryo of Palangka Raya City, Central Kalimantan Province, Indonesia. Kampung has some problem not only in term of the physical spatial pattern but also a socio-economic pattern in various strata as well as the various location in the urban area. The research question is how to describe of formal and informal integration by formal and informal activities within Kampung Pahandut. How to assess formal-legal status of Kampung regarding improve their settlement? The primary objective of this research is to describe of formal and informal integration by formal and informal within Kampung. It examines 
Kampung without obtaining formal-legal status of Kampung in regard to improve their settlement. This paper argues that the illegality of the kampung should be understood beyond the present formal regulatory framework. The socio-cultural background such as working together (gotong-royong) should be better understood to develop policy (Giyarsih, 2012). This social cultural policy is an important part to improve settlement in the future of kampung.

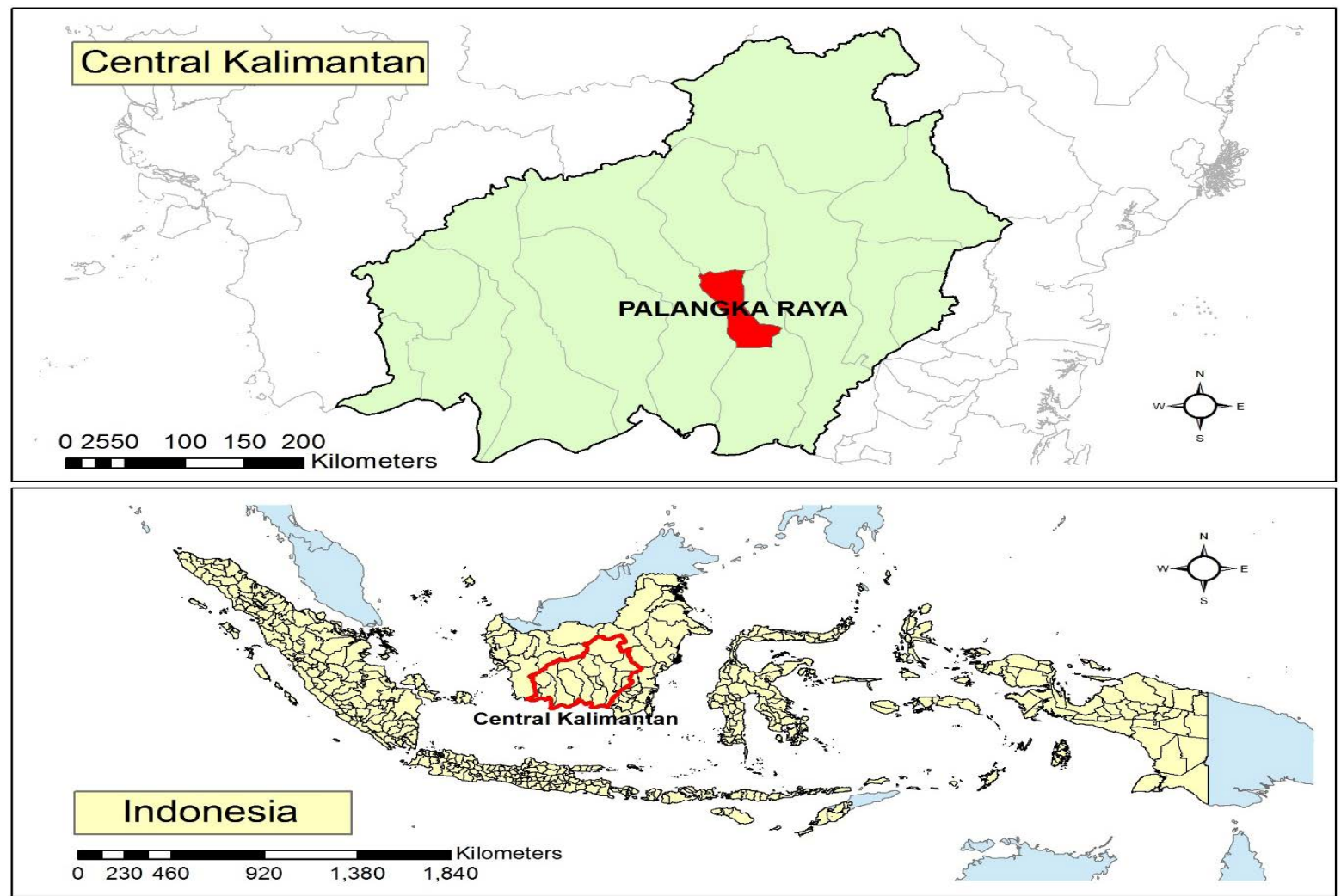

Figure 1. Location of Study

\section{Conceptual Framework: Integration} Model: Kampung Historical Background

In Javanese culture the term kampung is often associated with backwardness and shame, in contrast to the modern urban culture of the noble class (Guiness 1986; Raharjo, 2010). In colonial Batavia, kampung was inhabited by indigenous and non-European resident, as van der Molen (1993) puts it:

The separation between the living quarters was maintained to a certain extent during the nineteenth century: the Europeans settled in the new or upper town and along the main road between the old and the new town, the non-European inhabitants took possession of the old or lower town or lived in districts, interspersed among the European districts, the so-called kampung. The distinction between the Indonesia immigrants themselves, how- ever, disappeared gradually, to be replaced by the new amalgam of Orang Betawi, Batavians.

Van der Molen (1993) states there are two types of settlements existed in the fabric of Batavia: European settlement and kampung. European settlement which was inhabited by the Dutch and other residents of European descent was characterised by orderly built environment. Kampung was unplanned and haphazard settlement, inhabited mainly by indigenous residents and non-Europeans. Sullivan (1986) states in the context of colonial Yogyakarta whichcategorises colonial kampung into three types: residential compounds for the Javanese and various foreign or non-Javanese (Chinese, European, Arab, and India). These residential areas were named according the dominant profession of the inhabitants. 
Sullivan (1986) suggests that Kampung typology in that all type of residential areas in the colonial Yogyakarta were called kampung, regardless of their quality. By contrast Flieringa sees kampung in term of physical and social condition (Sullivan, 1986; Polle and Hofstee, 1986; cited by Raharjo, 2010). Flieringa (in Polle and Hofstee, 1986) argues that kampung in urban Indonesia were a result of gradual transformation of the desa (village) after the passing of the Dutch Decentralization Law in 1903, which led to the formation of European urban communities similar to gemeenten (municipalities) in the Netherlands. The jurisdiction of such municipalities, however, did not reach the desa, which was inhabited by the indigenous people and administered by inlandsche gemeenten (indigenous municipalities).

Flieringa (in Polle and Hofstee, 1986) further argues that the rural-urban migration led to the urbanisation of inlandsche gemeenten.

These inlandsche gemeenten are not anymore called desa, but kampung; the difference is that a kampung, in contrast to a desa, has no links or hardly any with agricultural land but the land is almost entirely used for residential purposes. The city kampung are mixed neighborhoods for impoverished Europeans (with category includes descendants of male Europeans and indigenous women), foreign Orientals and indigenous people, The desa association is almost completely lost; as a corporation the kampung that has retained hardly any significance; the people of the kampung do not bestow much care on the public works so that one finds annoying signs of neglect everywhere (cited by Polle and Hofstee, 1986).

This description closely matches the characteristics of the built environment of kampung today; haphazard, unplanned, mostly unmapped. Figure 2 shows part of Yogyakarta in the early twentieth century, where the Dutch housing estate called Kotabaru (New Town) looks well ordered, while the grey areas are the unmapped kampung.
The haphazard of today's kampung stems from the way in which the city was planned in colonial times. Kampung has its own long history as informal settlements where millions of people in the country live in. Kampung shows its capacity to integrate formal and informal activities both within the kampung itself and activities at city level. The integration of formal and informal activities in a kampung shows that dichotomous model of urban policy have no their empirical arguments. Kampung shows the integration of formal and informal activities.

Integration between formal and informal sectors in the context of urban settlements development has its long history. Karsten (1917) in planning the new city of Candi Semarang had introduced the integration concept of different income and different ethnic groups of Semarang City. Karsten (1917) classified the new city of Candi into three categories of house types: large houses, small houses, and smallest houses (Pratiwo, 2005). Karsten (1917) introduce a concept that is in the 1980's had been developed by the Ministry of People Housing of Indonesia with its very famous concept of 1:3:6. Concept of 1:3:6 means that all developers (particularly in the greater area of Jabotabek) have responsibility to build houses under this following regulation: every 1 unit of a house for high-income group to be built, should be followed by 3 units of house for middle income and 6 units of house for lowincome groups.

The improvement of Kampung had been conducted by Dutch Colonial Government in 1939. It indicates that integration of informal sector (kampong settlements) and formal sector (government intervention) has its root (Wertheim, 1958). This concept of Kampung improvement had been implemented since after Indonesian freedom in 1968. This concept was revitalised by the Indonesian Government through Kampung Improvement Program (KIP). The name of KIP project is derived from Husni Tamrin project, which was executed in Jakarta. In 1972 onward (up to 1992), this Kampung Improvement Programs have been enlarged to all cities of the country under the World Bank Projects. 


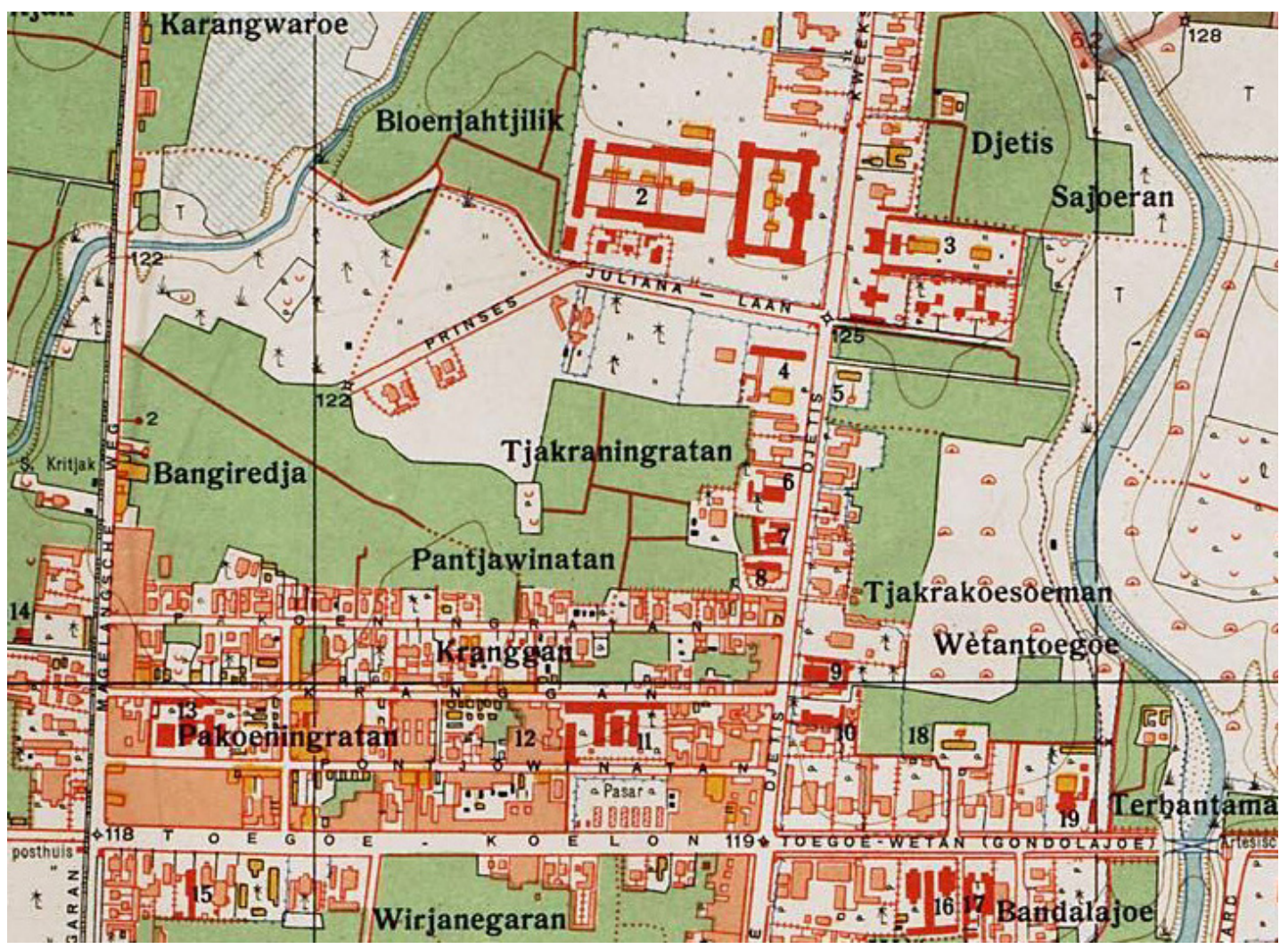

Figure 2. Kotabaru, Yogyakarta in 1925 (Source: extracted from map by the Royal Tropical Institute, 2009-modified by Raharjo [2010])

In 1992, Kampung Improvement Program has been stopped by World Bank. New approaches of urban development of the country have been introduced, such as: rented apartment (Rumah susun sewa), ownership apartment (Rumah Susun Milik), super block, and compact city. All concepts or model is that have been introduced, the compact city concept seems to have its substance of integration concepts, although the compact city concept is exclusively intended for middle and high-income groups. This research has tried to adopt the compact city concept to research on kampung not on its physical aspect of the concept, but on its spirit of integrating the plurality of settlements (Kusno, 2012).

As a term or a label, the 'integration formal and informal settlement model' is a relatively new term in the discussion of urban planning and development. The concept of integration has its long history by people living in traditional settlements and also in kampung of Indonesian cities. The activity of integration has been conducted by people living in a kampung and supported by the kampung facilities meets the spirit people. This research based on spirit is adopted under the terms of 'kampung' and used as a working concept of this research. The concept of 'kampung' is largely covered by integration of formal and informal sectors of kampung. The integration has taken from 'kampung activity'. The integration measured through 2 dimensions: physical integration and social integration. Through analysis of integrations, the integration of formal and informal sectors within the kampung and compactness between informal sector of kampung and formal sector of the city of Palangka Raya could be understood.

\section{Research Method}

This study is of an exploratory and evaluative nature settlement in kampung urban riverside settlement, with emphasis on a qualitative and quantitative research method. A large amount of quantitative data was compiled and used in this research; most of the analysis developed in this study is based on qualitative data and information. This study 
employs a social-economy perspective which takes the view that land and housing markets are not exclusively determined by economic factors. The social and cultural dimensions are thought to be of at least equal importance.

The focus of this study is the kampung along the bank of the Kahayan River in Palangka Raya City, Indonesia namely Kampung Pahandut (see Figure 3) as a case study by historical view ('the embryo' settlement of Palangka
Raya City). The settlements or kampung along the Kahayan River stretch along ten kilometres, from the north to the south of the city of Palangka Raya, and provide housing for a large member of the city's poor. Kampung people along the Kahayan River experience the effects of environmental and economic pressures to a greater extent than do other urban dwellers of Palangka Raya, yet have the least resources to solve these problems.

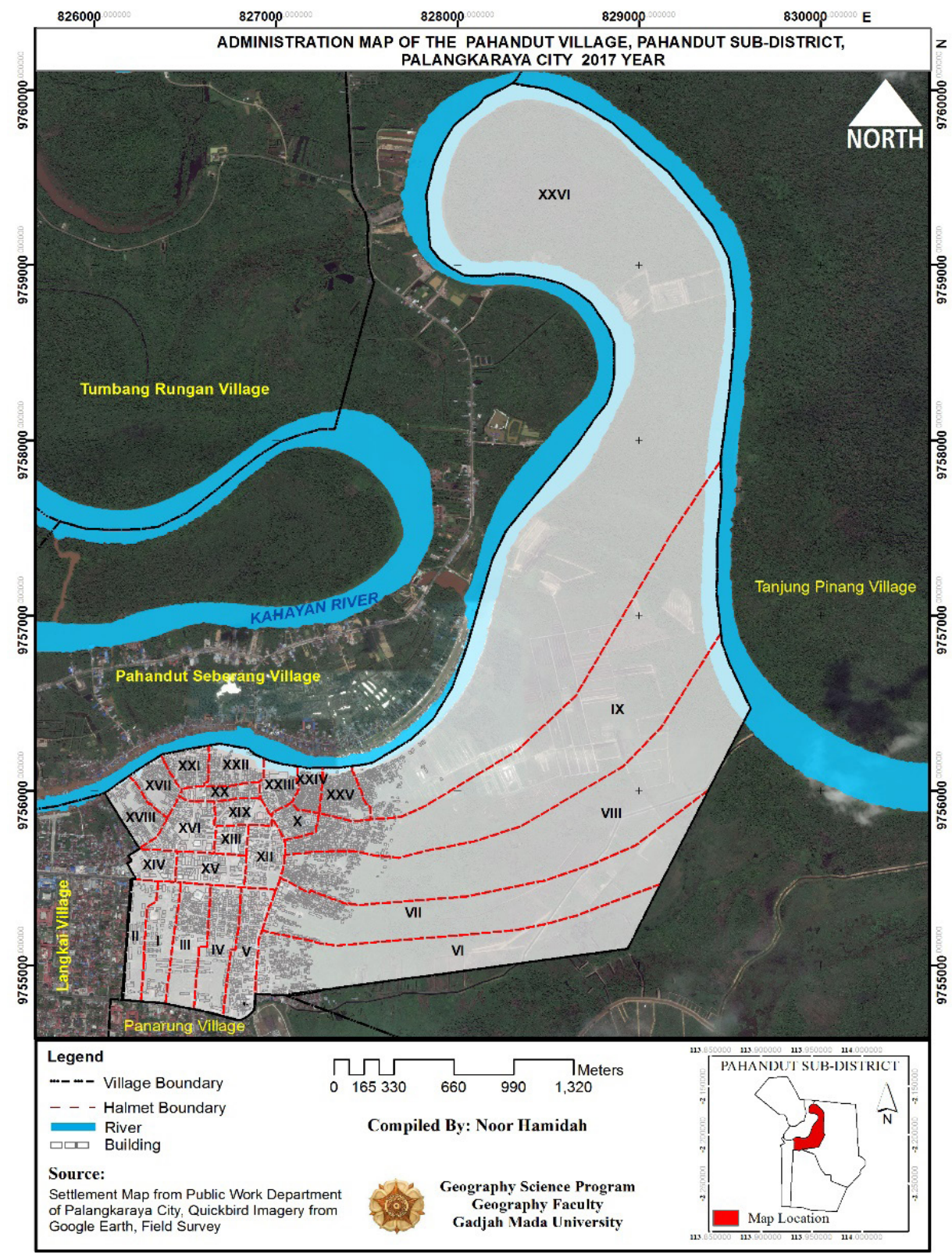

Figure 3. The Location of Research in Kampung Pahandut, Palangka Raya City, Indonesia. Source: Quickbird Imagery from Google Earth

The city itself can be considered as a centre of Kalimantan culture, while its role in the development of the new Republic of Indonesia in the 1957s made Palangka Raya into a special place for Indonesians. It is now the capital city of the Palangka Raya, Central Kalimantan 
Province, Indonesia. In 1995, the municipality of Palangka Raya had a population of 244,500 ; it is, by Indonesian standards, considered to be a medium-sized city. The total area of Kampung Pahandut is 950 ha or $9.5 \mathrm{~km} 2$ with the total population of 85,591 household (Palangka Raya Central Statistical Agency, 2014). The administrative boundary of Kampung Pahandut consist of: (1) the north is Pahandut Seberang village; (2) the east is Tanjung Pinang village; (3) the south is Panarung village; (4) the west is Langkai village. Selected sample refer to case study of Kampung Pahandut with total sample of 100 head household.

However, as urban growth has expanded beyond the boundaries of the municipality and the area has become the place of residence for about one million people, Palangka Raya becomes a medium-size city. The city is undergoing rapid development and transformation (Giyarsih, 2011). This includes the displacement, consolidation, and transformation of urban kampung in the city centre; the formation of new kampung on the urban fringe; and the incorporation and transformation of rural villages into urban kampung. As many number of kampung become overcrowded, the incoming migrants settle on 'marginal' land, such as river banks, and vacant land throughout the city. The process of kampung formation in Palangka Raya is still occurring and is creating massive headaches for the urban government, which wishes to develop a modern and orderly city.

Exploration in this study of Kampung Pahandut selected by the first community association is called Rukun Warga/RW (RW21) that consists of RT (neighbourhood association) from RT-1, RT-2, RT-3 and RT-4. The study was conducted to observe in the field and interviews with respondents household heads in each RT and in each RW located in a Kahayan urban riverside settlement, to know it is detailed data of the formal and informal physical development. Three steps were used to find out the integration through the followings: (1) the preparation of the study which is the initial activity carried out to map the location of research by mapping points of potential physical integration in Kampung Pahandut, District Pahandut. (2) the field survey through field observation and interviews with neighbor head. (3) the postfieldwork that is data processing which was done after the field activities focused on the formal and informal integration by physical and social activities of Kampung.

\section{Results and Discussions}

This research aims to explore empirical evidence of formal and informal integration by sector physical and social of kampung. The formal and informal integration are measured through evidences of integrations of physical and social dimensions of kampung within the kampung itself, and between the kampung and the city of Palangka Raya.

\section{a. Physical Integration}

One important characteristic of Kampung is as a strong integration form of urban land and settlement in Indonesia. We find out physical formal and informal integration of kampung in urban riverside settlement related to infrastructure. Kampung is characterised by complex and always unclear status. Most of the village was in a state of 'gray' legal on one or several aspects for example certified land status and are not legal in infrastructure aspects. Kampung status has intricate complexity, particularly with regard to the future of the Kampung and its improvement efforts. This study examines the status of kampung 'fuzzy' and recommend what policy should be taken.

Kampung Pahandut Improvement Program is a government program which reflects the attention and awareness of the city government toward the improvements of environmental quality of kampung. Kampung in Indonesia has legal administration, that is kampung a part of city planning. Kampung can be found in regional or district map see Figure 3 , which is recognised by the Neighbourhood Association (Rukun Tetangga/RT) and Community Association (Rukun Warga/RW). Kampung has spatially possible to have this program received financial supports from 
the city government. In general, the budget physical proposal submitted by people to the city government for example 'green kampung' program was approved.

Physical integration between community's programs and the government programs appearing in the forms of road construction, drainage construction, water distribution, electricity connection.
Infrastructure improvements of kampung supported by Palangka Raya government included funding of healthy facility and social facility (see Figure 4). It indicates that kampung are inclusively included in the developments map of the city government. The policy and development actions of Palangka Raya city is considered to improve kampung infrastructure as a part of city planning.

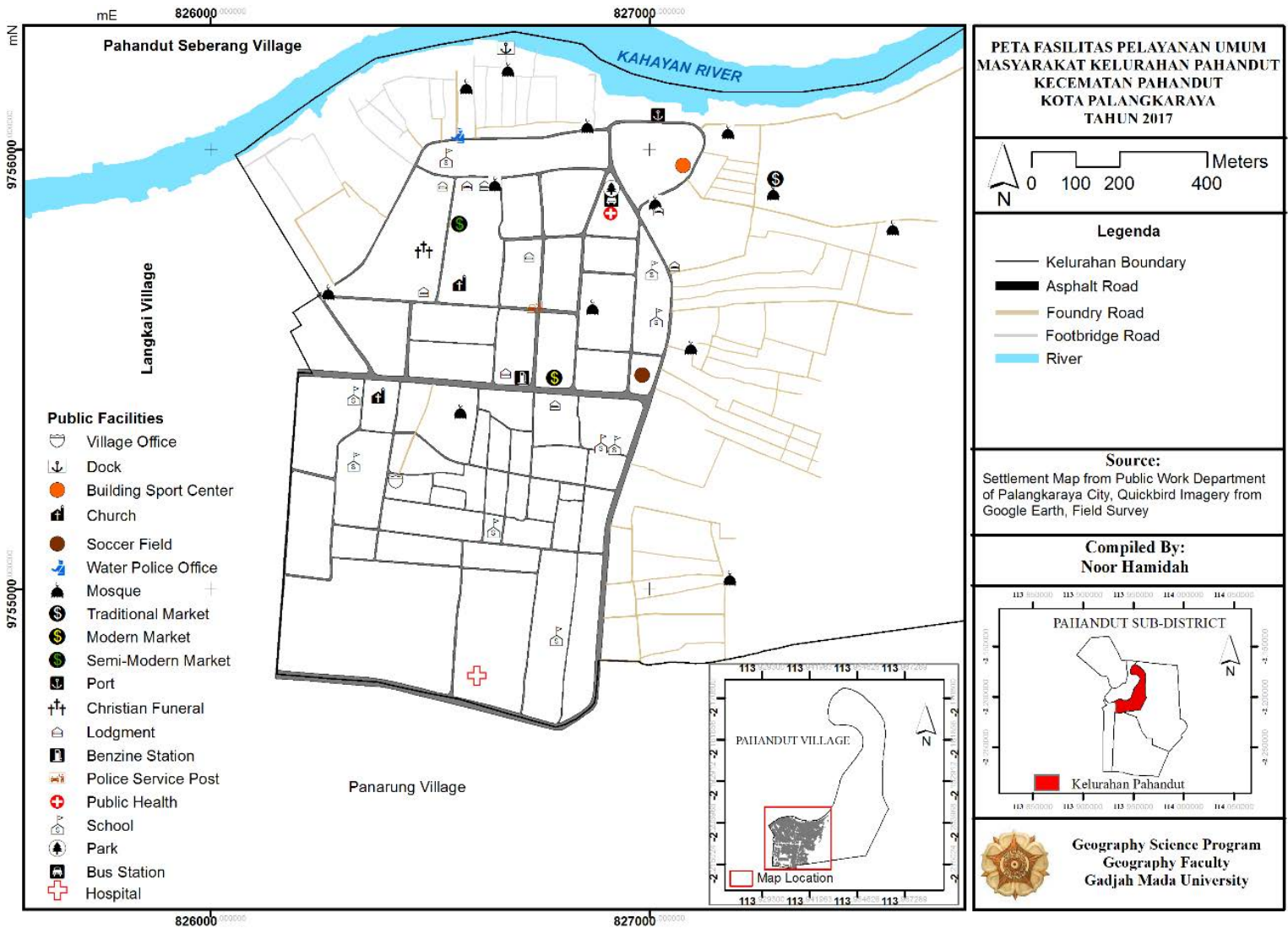

Figure 4. Map of Infrastructure i.e. Road Construction of Formal (Road), Semi Formal Road, Informal Road/Wooden Bridge, Social Facility, and Economic Facility (Source: field observation, 2016 drawing by arc Map 3.10.1)

It is noted that infrastructure did not obtain property titles. The KTP (ID cards) granted by the government has enabled residents to access state-supported facilities, such as building public facilities and infrastructure upgrading (see Figure 4). The development and improvement of roads and drainage is almost for all kampung communities working together with the city government of Palangka Raya through block grant program. Figure 5 shows the physical program which has constructed road by asphalt, integrated to concrete road which has been constructed by kampung peoples funded by government (Kampung Improvement Program/P2KP). Concrete road has integrated to jalan titian kayu (wooden bridge) constructed by dominant local people in Kampung Pahandut. P2KP program is to involve local people executed through stage of planning, financing, constructing, and maintaining. P2KP is a part of improved physical program of Palangka Raya government. The maintenance of roads and drainage is usually done by the community.

The mechanism used in this type of infrastructure development is that, people 
through a community meeting designed a proposal and submit it to the city government; the government, through a consulting meeting decide and approve the proposal and the budget (usually $70 \%$ was agreed to be financed by the government and $30 \%$ of the rest of the budget was financed by the community). The interesting situation which occurs in the community meeting is that, on the 30 per cent of the budget which has to be financed by the community, it was collected through a voluntarily participation; meaning that those who belong to the middle-income group contribute more than those of the low-income group and the very poor people group of the kampung. This situation indicates that feeling of togetherness (social capital) has a significant role as underpinning development of kampung.

Integration between kampung and city could be indicated through: (i) use of the same access; (ii) using common spaces; and (iii) using same infrastructure connection. The existence of public and private buildings (formal sector) in the middle of kampung also indicates that a kampung is not inferior settlement, Government office, children school, NGO office, private university, and private office are found in the middle of kampung.

\section{b. Social Integration}

Social integration concept in this research including all social activities, all social organisations, all social contracts, and all social consensuses of people living in the kampung. Social integration concept will be able to bring all people "get together" and produce social progress which further contribute to social life of the kampung. Social integration in the context of Kampung Pahandit, district of Pahandut, Palangka Raya City can be identified into two levels: kampung social integration at city level (external social level) and RT/ RW social integration at kampung level (internal social level). External and internal social activity did not obtain property titles. The KTP (ID cards) granted by the government has enabled residents to access social facilities, such as funding for social activity internal or external kampung (see Figure 5).

External social integration through social activities shows that kampung are not isolation settlements. The integration of kampung with the outer institutions show in Figure 5 with the forms of: (i) inter-kampung networking, meaning some kampung with the closed distance built a forum of communication for discussing commons problem of kampung; (ii) art and cultural performances at city level which are facilitated by the government; (iii) external social organization (NGO) which has its branch office in kampung; and (iv) links with the city government offices under the programs of social safety networks. External integration is a part of social city planning and kampung program, i.e. 'say no to drug' program and 'no smoking area' program is done every month in Kampung Pahandut office. External social activities involves of all people from Kampung Pahandut.

Kampung has a program external social is called 'green kampung'. This social external integration is called babarasih kampung (river cleaning). Babarasih kampung is one of popular activities which contribute much to the environmental sustainability within kampung itself and Palangka Raya city. The spirit of social integration according to the city government is to improve communication and tolerance of people living in the kampung of Palangka Raya. Babarasih kampung done by people from kampung and also people from city working together (gotong-royong). This project is a part of the government program of building Palangka Raya as a "city of tolerance". Field observations found that the social building or area in Kampung Pahandut provided by the government: sports, public meeting, arts and cultural events, etc. 


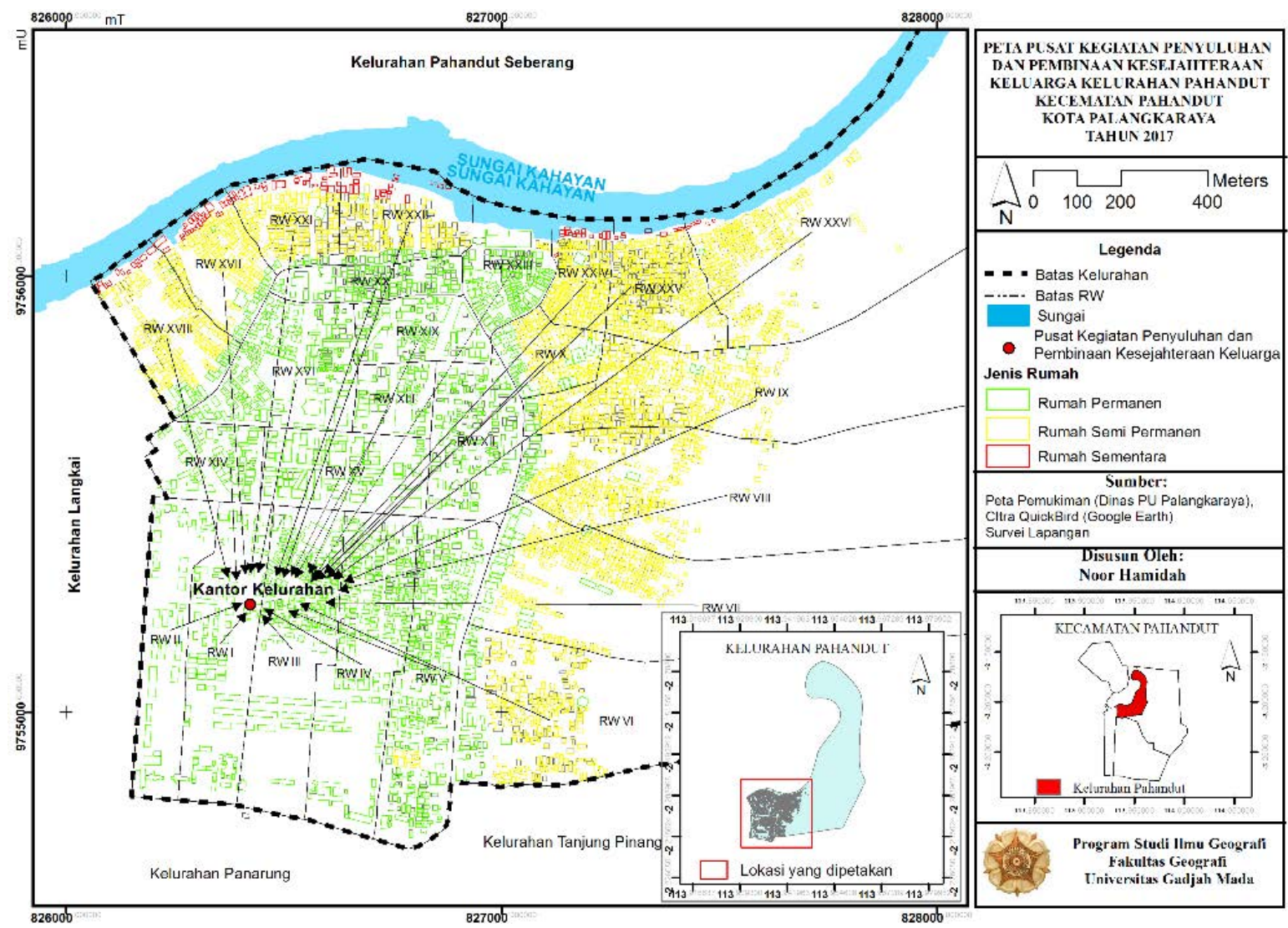

Figure 5. Map of Social Activity 'Say No to Drug' Monthly Meeting Conducted in Kampung Pahandut Office (Source: field observation, 2016)

The internal social integration includes all activities conducted in RW such as: dasa wisma (women meeting), posyandu (baby healthy consultation), sports, pengajian (Holy Qur'an study), arts and cultural event, pop music, youth organisation. In general this research found that at the internal kampung level, social integration among all people lives in the kampung occurs and works every month. Social activity did not obtain property titles. The KTP (ID cards) granted by the government has enabled residents to access state-supported facilities, such as building public facilities and infrastructure upgrading (see Figure 5).

Among the above themes of internal social integration, it is found that dasa wisma (women meeting) is a popular activities each RT or RW and exists in all kampung of Palangka Raya. This finding indicates that the role of woman in the integration of social life in the kampung is very significant. Dasa wisma (women meeting) is a monthly forum of women, where all women in the kampung meet in a semi-formal meeting, to discuss many topics of social activities such as: improvement of child nutrition, mother healthy, etc. Local people have a physical improvement program i.e. wooden bridge construction, river cleaning, safety kampung night, etc.

\section{Conclusions}

The acceptance of the city government to the existence of kampung and to include kampung in the development map of the city indicates that kampung as an existence of space is not an interior space compared to other spaces of the city. Kampung has its significant contributions to the economic life of Palangka Raya city. The integration of kampung to the city level of sociocultural and economical life is parallel with the integration of infrastructure development showing that compactness between kampung and the city of Palangka Raya is there. Formal and informal integration reflecting kampung activity is not just a reflection of strong internal integration within the kampung itself, but it is also structured by a strong external integration. A kampung is a part of city planning. 
The research comes out with three typologies of integration of "kampung". The first type of typology is shown by the present of "social" and "social" integration, meaning that internal social integration in the forms of social institutions and socio-cultural activities of the kampung has its strong connection with the related institutions and activities at city level. The second type of typology is shown by "social" and "spatial" integration, indicated by use of public spaces as meeting point of people to integrate each other. Through public space distribution and uses, the social pattern of people interactions in the kampung could be known. The spirit of social integration according to the city government is to improve communication and tolerance of people living in the kampungs of Palangka Raya. Babarasih kampung done by people from kampung and also people from city working together (gotong-royong). This project is a part of the government program of building Palangka Raya as a "city of tolerance".

The last typology that is "spatial" to "spatial" integration could be found in the openness of kampung to receive new development introduced in some kampung of Palangka Raya, as shown by Kampung Pahandut Improvement Program which is a government program which reflects the attention and awareness of the city government toward the improvements of environmental quality of kampung. All kampung in Indonesia which are spatially possible to have this program received financial supports from the city government. In general, the budget proposal submitted by people to the city government for kampung greenery program was approved.

\section{Acknowledgement}

The author would like to thanks to Directorate of Research and Social Services, RISTEKDIKTI gives funding to this Doctoral Dissertation Skim based on MoU agreed with LEMLIT Palangka Raya University (under the contract of No: 01.038/UN24.8/ PL/ 2016). Thanks to Rector of Palangka Raya University to give a chance to study in Faculty of Geography, Universitas Gadjah Mada. Thanks to Rector of Universitas Palangka Raya supports my study and also Students from Architecture of Department of Architecture, Palangka Raya University, who help much in conducting field work of this research in Palangka Raya City. Thanks to Lurah Pahandut, Head of Pahandut Village on in-depth interviews related to Kampung of Pahandut settlement history.

\section{References}

Baiquni, M. (2000) Social-Economics Integration of Dualistic Settlement Environment at Urban Areas in Indonesia (Case Study in Yogyakarta City). Forum Geografi, Vol. 14 No. 1.

Burgess (1985) Problems in the Classification of Low Income Neighborhoods in Latin America. Third World Planning Review. Vol. 4. No.7: 287-306.

Colombijn, F. (2010) Under Construction: The Politics of Urban Space and Housing during the Decolonization of Indonesia, 1930-1960. Leiden: KITLV Press.

Doebelle, William A. (1987) The Evolution of Concepts of Urban Land Tenure in Developing Countries in Habitat International, Vol. 11, No.1.

Doxiadis, Constantinos A. (1968) Existics: An Introduction to the Science of Human Settlement. Hutchinson, London.

Giyarsih, S., R. (2011) The Impact of Regional Transformation on the Cultural Condition of The Citizen (A Review of Geography Perspective). Forum Geografi, Vol. 26. No. 2, pp: 120-131.

Groat, L. and Wang, D. (2000) Architectural Research Methods, John Wiley\&Sons, NewYork. Washington: World Bank.

Government of Palangka Raya City (2003) Sejarah Kota Palangka Raya. 
Guiness, P. (1986) Harmony and Hierarcy in a Javanese Kampung. Singapore: Oxford University Press.

Hart, K. (1973) Informal income opportunities and urban in Ghana. Jurnal of Modern African Studies, 11(1),61-89. International Labor Office (1972). Employment, income and equality: A strategy for increasing productivity in Kenya. Geneva: ILO.

Karsten, T. H. (1917) Nieuw Tjandi, in van van Roosmalen \& K. M. Pauline. 2005. Expanding Grounds: The Roots of Spatial Planning in Indonesia, in F. Colombijn, M. Barwegen.

Kusno, A. (2012) Politik Ekonomi Perumahan Rakyat dan Utopia Jakarta. Publised Ombak: Jakarta.

Lim, G. (1987) Housing Policies for the Urban Poor in Developing Countries. APA Journal, Spring. Palangka Raya Local Regulation (1990) No. 1, 1990 (Perda No. 1/1990).

Performance Based Building Network (PeBBu) (2004) Compact city: Domain 4 - Performance Based Building Environment, Performance Based Building Network, European Commission's 5th Framework. Retreived September 6, 2008, from http://www.rdg.ac.uk/Pebbu/ state_of_ art/urban_approaches/ compact_city.

Polle, Victor FL and Hoftsee, P. (1986) Urban Kampung Improvement and the Use of Aerial Photography for Data Collection, in Nas, PJM (ed.), The Indonesian City: Studies in Urban Development and Planning, Foris, Dordrecht.

Pratiwo, P. (2005) the city planning of semarang 1900-1970, in F. Colombijn, M. Barwegen, P. Basundoro, \& J.A. dan Khusyairi, 2005, Kota Lama Kota Baru, Ombak, Yogyakarta

Raharjo, W. (2010) Speculative Settlements: Built Form/Tenure Ambiguity in Kampung Development, PhD Dissertation, Melbourne of University, Australia.

Sastrosasmito, S. (1990) Housing for informal sector workers: The case of Yogyakarta, Indonesia. Habitat International Journal, 14 (4), 75-88.

Sastrosasmito, S. (1992) The future of Self-help housing", Ekrtics, 59, pp.354-355.

Sastrosasmito, S. (2009) Compact Kampungs: Formal and Informal Integration in the Context of Urban Settlements of Yogyakarta. Journal of Habitat Engineering, Vol. 1 No.1. pp.119-134.

Sullivan, J. (1986) Kampung and State: The Role of Government in the Development of Urban Community in Yogyakarta', Indonesia, 41, pp.63-88.

Setiawan, B. (1998) Local Dynamics in Informal Settlement Development: A Case Study of Yogyakarta, Indonesia, PhD Dissertation, University of Columbia.

Setiawan, B. (2001) The Future of Kampung in Indonesia: Costs and Benefits of Illegality. Journal of Forum Teknik Jilid 25 No. 2, Edisi Juli 2001.

UN-Habitat (2003) Settlement Agenda for the Development of Sustainable Quality of Life.

Van der Molen, W. (1993) 'Glory of Batavia: The Image of a Colonial City through the Eyes of a Javanese Nobleman', in Nas, PJM (ed.), Urban Symbolism, EJ Brill, Leiden and New York.

Wertheim, W.F. (1958) The Indonesian town: Studies in urban sociology, Amsterdam: The Royal Tropical Institute. 